\title{
Occurrence and molecular characterization of hemoplasmas in domestic dogs and wild mammals in a Brazilian wetland
}

\author{
Keyla Carstens Marques de Sousa ${ }^{\mathrm{a}}$, Heitor Miraglia Herrera ${ }^{\mathrm{b}}$, Caroline Tostes Secato ${ }^{\mathrm{a}}$, \\ André do Vale Oliveira ${ }^{\mathrm{a}}$, Filipe Martins Santos ${ }^{\mathrm{b}}$, Fabiana Lopes Rocha ${ }^{\mathrm{c}}$, \\ Wanessa Teixeira Gomes Barreto ${ }^{\mathrm{b}}$, Gabriel Carvalho Macedo ${ }^{\mathrm{b}}$, \\ Pedro Cordeiro Estrela de Andrade Pinto ${ }^{c}$, Rosangela Zacarias Machado ${ }^{a}$, Mirela Tinucci Costa ${ }^{a}$, \\ Marcos Rogério André ${ }^{a, *}$
}

\footnotetext{
${ }^{\text {a } U n i v e r s i d a d e ~ E s t a d u a l ~ P a u l i s t a ~(U n e s p), ~ F a c u l d a d e ~ d e ~ C i e ̂ n c i a s ~ A g r a ́ r i a s ~ e ~ V e t e r i n a ́ r i a s, ~ J a b o t i c a b a l, ~ S P, ~ B r a z i l ~}$

b Universidade Católica Dom Bosco, Campo Grande, MS, Brazil

c Universidade Federal da Paraíba, Laboratório de Ecologia Animal, Rio Tinto, PB, Brazil
}

\section{A R T I C L E I N F O}

\section{Keywords:}

Mycoplasma spp.

Wild carnivores

Wild rodents

Pantanal

\begin{abstract}
A B S T R A C T
Hemotropic mycoplasmas are known to cause anemia in several mammalian species. The present work aimed to investigate the occurrence of Mycoplasma spp. in wild mammals, domestic dogs and their respective ectoparasites, in southern Pantanal region, central-western Brazil. Between August 2013 and March 2015, 31 Nasua nasua, 78 Cerdocyon thous, seven Leopardus pardalis, 42 dogs, 110 wild rodents, and 30 marsupials were trapped and ectoparasites (ticks and fleas) found parasitizing the animals were collected. Mammals and ectoparasites DNA samples were submitted to conventional PCR assays for Mycoplasma spp. targeting 16S rRNA and RnaseP genes. Twenty-four $N$. nasua, three $C$. thous, two domestic dogs, one $L$. pardalis and one wild rodent were positive for $16 \mathrm{~S}$ rRNA PCR protocols. Fourteen $N$. nasua samples were also positive in RnaseP PCR. No marsupial or arthropod showed positivity for Mycoplasma spp. The phylogenetic analyses based on 16S rRNA gene showed that all sequences obtained from dogs, two sequences obtained from $C$. thous and ten sequences obtained from $N$. nasua showed to be closely related to Mycoplasma haemocanis/Mycoplasma haemofelis species. Genotypes closely related to 'Candidatus Mycoplasma haemominutum' and Mycoplasma haemomuris were detected in the L. pardalis and in the wild rodent, respectively. Probably a novel Mycoplasma genotype, closely related to a sequence obtained from a Brazilian capybara was detected in $14 \mathrm{~N}$. nasua, based on a concatenated phylogenetic analysis of $16 \mathrm{~S}$ rRNA and RnaseP genes. The present study revealed that wild animals in southern Pantanal region, Brazil, are exposed to different species of hemoplasmas.
\end{abstract}

\section{Introduction}

Hemotropic mycoplasmas (hemoplasmas) are epicellular erythrocytic bacteria lacking cell wall. In contrast to several mucosal mycoplasmas, hemoplasmas have never been grown successfully in culture so far. These pathogens are known to be the causative agents of infectious anemia in several mammalian species and may induce acute hemolysis in some cases (Tasker, 2010). The disease is characterized by anorexia, lethargy, dehydration, weight loss and in some cases, can lead to death (Willi et al., 2007). Furthermore, hemotropic mycoplasmas are considered emergent zoonotic agents, mainly in immunocompromised individuals or those highly exposed to arthropod vectors (dos Santos

\section{et al., 2008; Maggi et al., 2013a).}

The transmission of hemoplasmas between domestic cats and dogs seems to occur mainly by bloodsucking arthropods, such as ticks and fleas, blood transfusion, contaminated fomites and transplacentally (Seneviratna et al., 1973; Messick, 2003; Lappin et al., 2006). In addition to this, infections through biting and fighting are considered another possible routes of hemoplasma transmission (Tasker, 2010).

Although hemoplasmas have been detected in domestic cats (Braga et al., 2012; Miceli et al., 2013; André et al., 2014; Santis et al., 2014) and dogs (Ramos et al., 2010; Alves et al., 2014; Valle et al., 2014; Soares et al., 2016) from several localities in Brazil, few reports have documented the occurrence of hemoplasma species in wild animals. For

\footnotetext{
* Corresponding author at: Laboratório de Imunoparasitologia, Departamento de Patologia Veterinária, Faculdade de Ciências Agrárias e Veterinárias Júlio de Mesquita Filho (UNESP), Campus de Jaboticabal, Via de Acesso Prof. Paulo Donato Castellane, s/n, Zona Rural,Jaboticabal, SP, CEP: 14884-900, Brazil.

E-mail address: marcos_andre@fcav.unesp.br (M.R. André).
} 


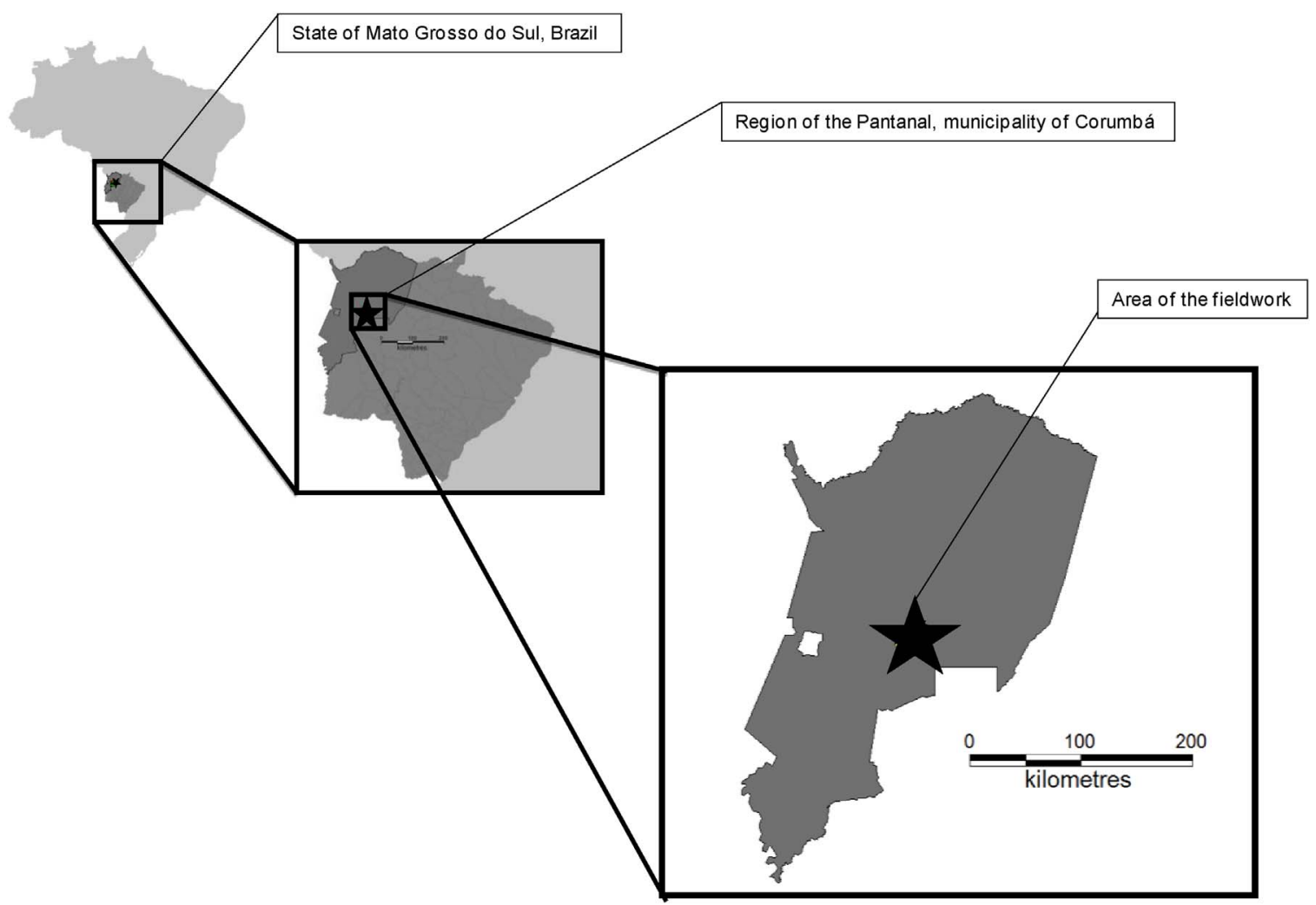

Fig. 1. Capture sites. Map of Mato Grosso do Sul State, central-western Brazil, showing the Pantanal region, where animals samples were collected in the present study.

instance, hemoplasmas have been detected in wild carnivores maintained in captivity in zoos (Willi et al., 2007; Guimarães et al., 2007; André et al., 2011), wild rodents (Vieira et al., 2009; Conrado et al., 2015; Gonçalves et al., 2015), monkeys (Bonato et al., 2015), and deer (Grazziotin et al., 2011) in Brazil.

Due to the lack of information about the epidemiology and routes of transmission of hemoplasmas among the wildlife from Brazil, the present study aimed to investigate the occurrence of hemotropic mycoplasmas in wild mammals and domestic dogs and their respective ectoparasites in the region of Pantanal, state of Mato Grosso do Sul, central-western Brazil.

\section{Material and methods}

The fieldwork was conducted at the Nhumirim ranch $\left(56^{\circ} 39^{\prime} \mathrm{W}\right.$, $18^{\circ} 59^{\prime} \mathrm{S}$ ), located in the central region of the Pantanal, municipality of Corumbá, state of Mato Grosso do Sul, central-western Brazil (Fig. 1). This region is characterized by a mosaic of semi deciduous forest, arboreal savannas, seasonally flooded fields covered by grasslands with dispersed shrubs and several temporary and permanent ponds. The Pantanal is the largest Neotropical floodplain, being well known for its rich biodiversity. Two well-defined seasons are recognized in the studied region: a rainy summer (October to March) and a dry winter (April to September) (Sousa et al., 2017).

Between August 2013 and March 2015, a total of 256 mammals were captured in the central region of the Pantanal, municipality of Corumbá, state of Mato Grosso do Sul, including 158 carnivores, among 78 crab-eating foxes (C. thous), 31 coatis ( $N$. nasua) and seven ocelots (L. pardalis); 140 small mammals, among 110 wild rodents (77 Thrichomys fosteri, 25 Oecomys mamorae and 8 Clyomys laticeps) and 30 wild marsupials (14 Thylamys macrurus, 11 Gracilinanus agilis, 4 Monodelphis domestica and 1 Didelphis albiventris). Forty-two blood samples from domestic dogs cohabiting the same studied area were also collected. All animal captures were in accordance with the licenses obtained from the Brazilian Government Institute for Wildlife and
Natural Resources Care (IBAMA) (license numbers38145, 38787-2) and endorsed by the Ethics Committee of FCAV/UNESP University (Faculdade de Ciências Agrárias e Veterinárias, Universidade Estadual Paulista "Júlio de Mesquita Filho", Câmpus Jaboticabal) n 006772/13 (Sousa et al., 2017).

One thousand five hundred and eighty-two ticks parasitizing the sampled mammals were collected, including 1033 (65.2\% [115 adults and 918 nymphs]) Amblyomma sculptum Berlese specimens, 241 (15.2\% [78 adults and 163 nymphs]) Amblyomma parvum Aragão specimens, 32 (2\%) Amblyomma ovale Koch adults, one (0.06\%) Amblyomma tigrinum Koch adult, one (0.06\%) Rhipicephalus (Boophilus) microplus (Canestrini) adult, one (0.06\%) Rhipicephalus sanguineus s.l. (Latreille) adult, four (0.2\%) Amblyomma auricularium (Conil) nymphs, and 269 (17\%) Amblyomma larvae. Furthermore, a total of 80 Polygenis (Polygenis) bohlsi bohlsi (Wagner) fleas were also collected (Sousa et al., 2017).

DNA was extracted from $200 \mu \mathrm{L}$ of each whole blood (158 wild carnivores and 42 domestic dogs) and $10 \mathrm{mg}$ of spleen (140 small mammals) samples using the QIAamp DNA Blood Mini kit (QIAGEN ${ }^{\circ}$, Valencia, CA, USA), according to the manufacturer's instructions. The amount of tick DNA extracted was 523, of which 228 (43.5\%) were from adults, 256 (48.9\%) pooled nymphs, and 39 (7.4\%) from pooled larvae. While DNA extraction from ticks was processed in pools for nymphs (up to 5 individuals) and larvae (up to 10 individuals), the adults were processed individually. A total of 39 pooled fleas samples were submitted to DNA extraction. The fleas DNA extraction was also performed in pools consisting of up to five individuals. Ticks and fleas were macerated and submitted to DNA extraction, using the same kit before mentioned (Sousa et al., 2017).

In order to verify the presence of amplifiable DNA in the samples, internal control PCR assays targeting fragments of mammalian glyceraldehyde-3-phosphatedehydrogenase (GAPDH), ticks mitochondrial 16S rRNA and fleas cytochrome-c oxidase subunit I (Cox-1) genes were performed (Table 1). All 298 DNA animal samples amplified the predicted product for GAPDH gene. Out of 523 sampled ticks, 31 
Table 1

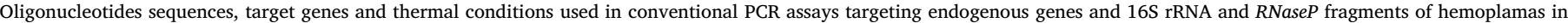
biological samples from wild mammals and domestic dogs, trapped and sampled, respectively, in southern Pantanal, state of Mato Grosso do Sul, central-western Brazil.

\begin{tabular}{|c|c|c|c|}
\hline Oligonucleotides sequences $\left(5^{\prime}-3^{\prime}\right)$ & Gene & Thermal conditions & References \\
\hline $\begin{array}{l}\text { GAPDH-F (CCTTCATTGACCTCAACTACAT) } \\
\text { GAPDH-R (CCAAAGTTGTCATGGATGACC) } \\
\text { 16S + } 1 \text { (CTGCTCAATGATTTTTTAAATTGCTGTGG) } \\
\text { 16S-1 (CCGGTCTGAACTCAGATCAAGT) }\end{array}$ & GAPDH/Mammals & $\begin{array}{l}95{ }^{\circ} \mathrm{C} \text { for } 5 \mathrm{~min} \text {; } 35 \text { cycles of } 95{ }^{\circ} \mathrm{C} \text { for } 15 \mathrm{~s}, 50{ }^{\circ} \mathrm{C} \text { for } 30 \mathrm{~s} \\
\text { and } 72{ }^{\circ} \mathrm{C} \text { for } 30 \mathrm{~s} \text {; and final extension of } 72{ }^{\circ} \mathrm{C} \text { for } 5 \mathrm{~min} \text {. } \\
10 \text { cycles of } 92{ }^{\circ} \mathrm{C} \text { for } 1 \mathrm{~min}, 48{ }^{\circ} \mathrm{C} \text { for } 1 \mathrm{~min} \text { and } 72{ }^{\circ} \mathrm{C} \\
\text { for } 1 \mathrm{~min} \text {, followed by } 32 \text { cycles of } 92^{\circ} \mathrm{C} \text { for } 1 \mathrm{~min}, 54{ }^{\circ} \mathrm{C} \\
\text { for } 35 \mathrm{~s} \text { and } 72{ }^{\circ} \mathrm{C} \text { for } 1,35 \mathrm{~min} \text {, and final extension of } \\
72{ }^{\circ} \mathrm{C} \text { for } 7 \mathrm{~min} \text {. }\end{array}$ & $\begin{array}{l}\text { Birkenheuer et al. } \\
\text { (2003) } \\
\text { Black and Piesman } \\
\text { (1994) }\end{array}$ \\
\hline $\begin{array}{l}\text { HC02198 (TAAACTTCAGGGTGACCAAAAAATCA) } \\
\text { LCO1490 (GGTCAACAAATCATAAAGATATTGG) }\end{array}$ & COX1/Fleas & $\begin{array}{l}95^{\circ} \mathrm{C} \text { for } 1 \mathrm{~min}, 35 \text { cycles of } 95^{\circ} \mathrm{C} \text { for } 15 \mathrm{~s}, 55^{\circ} \mathrm{C} \text { for } 15 \mathrm{~s} \\
\text { and } 72{ }^{\circ} \mathrm{C} \text { for } 10 \mathrm{~s} \text {, and final extension of } 72{ }^{\circ} \mathrm{C} \text { for } 5 \mathrm{~min} .\end{array}$ & Folmer et al. (1994) \\
\hline $\begin{array}{l}\text { HemMycop16S-41 s (GYATGCMTAAYACATGCAAGTCGARCG) } \\
\text { HemMyco16S-938as (CTCCACCACTTGTTCAGGTCCCCGTC) }\end{array}$ & $\begin{array}{l}16 \mathrm{~S} \text { rRNA } \\
1^{\circ} \text { set/ } \\
\text { Hemoplasmas }\end{array}$ & $\begin{array}{l}94^{\circ} \mathrm{C} \text { for } 2 \mathrm{~min}, 55 \text { cycles of } 94^{\circ} \mathrm{C} \text { for } 15 \mathrm{~s}, 68^{\circ} \mathrm{C} \text { for } 15 \mathrm{~s} \\
\text { and } 72{ }^{\circ} \mathrm{C} \text { for } 18 \mathrm{~s} \text {, and final extension of } 72{ }^{\circ} \mathrm{C} \text { for } 1 \mathrm{~min} .\end{array}$ & $\begin{array}{l}\text { Maggi et al. } \\
(2013 b)\end{array}$ \\
\hline $\begin{array}{l}\text { HemMycop16S- } 322 \text { s (GCCCATATTCCTACGGGAAGCAGCAGT) } \\
\text { HemMycop16S-1420as (GTTTGACGGGCGGTGTGTACAAGACC) }\end{array}$ & $\begin{array}{l}16 \mathrm{~S} \text { rRNA } \\
2^{\circ} \text { set/ } \\
\text { Hemoplasmas }\end{array}$ & $\begin{array}{l}94^{\circ} \mathrm{C} \text { for } 2 \mathrm{~min}, 55 \text { cycles of } 94^{\circ} \mathrm{C} \text { for } 15 \mathrm{~s}, 68^{\circ} \mathrm{C} \text { for } 15 \mathrm{~s} \\
\text { and } 72{ }^{\circ} \mathrm{C} \text { for } 18 \mathrm{~s} \text {, and final extension of } 72{ }^{\circ} \mathrm{C} \text { for } 1 \mathrm{~min} .\end{array}$ & $\begin{array}{l}\text { Maggi et al. } \\
(2013 b)\end{array}$ \\
\hline $\begin{array}{l}\text { HemoMyco RNaseP30 s } \\
\quad \text { (GATKGTGYGAGYATATAAAAAATAAARCTCRAC) } \\
\text { HemoMyco RNaseP200as (GMGGRGTTTACCGCGTTTCAC) }\end{array}$ & $\begin{array}{l}\text { RNaseP/ } \\
\text { Hemoplasmas }\end{array}$ & $\begin{array}{l}94^{\circ} \mathrm{C} \text { for } 2 \mathrm{~min}, 55 \text { cycles of } 94^{\circ} \mathrm{C} \text { for } 15 \mathrm{~s}, 59^{\circ} \mathrm{C} \text { for } 15 \mathrm{~s} \\
\text { and } 72{ }^{\circ} \mathrm{C} \text { for } 18 \mathrm{~s} \text {, and final extension of } 72{ }^{\circ} \mathrm{C} \text { for } 1 \mathrm{~min} .\end{array}$ & $\begin{array}{l}\text { Maggi et al. } \\
\text { (2013b) }\end{array}$ \\
\hline
\end{tabular}

(5.9\% [23 A. parvum adults, 4 A. sculptum adults, 1 A. ovale adult, 1 A. parvum nymph and 2 pooled Amblyomma larvae]) showed negative results for the tick mitochondrial 16S rRNA gene and were excluded from subsequent analyses. Only one flea DNA sample did not amplify the predicted product for cox-1 and was also excluded from subsequent analyses (Sousa et al., 2017).

Previously described PCR protocols based on 16S rRNA gene were performed in order to amplify Mycoplasma spp. DNA, using two sets of oligonucleotides (Table 1). Five microliters of DNA were used as a template in $25 \mu \mathrm{L}$ reaction mixtures containing 10X PCR buffer, $1.0 \mathrm{mM}$ $\mathrm{MgCl}_{2}, 0.8 \mathrm{mM}$ deoxynucleotide triphosphate (dNTPs) mixture, $1.5 \mathrm{U}$ Taq DNA Polymerase (Life Technologies ${ }^{\circ}$ ) and $0.3 \mu \mathrm{M}$ of each oligonucleotide. Mycoplasma haemofelis DNA obtained from a naturally infected cat (Miceli et al., 2013) and ultra-pure sterile water were used as positive and negative controls, respectively. 16S rRNA-Mycoplasmaspp.positive samples were additionally submitted to a previously described RNaseP gene-Mycoplasma spp. (165 bp) PCR assay (Table 1). The sequencing was performed using the BigDye ${ }^{\varpi}$ Terminator v3.1Cycle Sequencing Kit (Thermo Fisher Scientific ${ }^{\circ}$, Waltham, MA, USA) and ABI PRISM 310DNA Analyzer (Applied Biosystems ${ }^{\circledR}$, Foster City, CA, USA) (Sanger et al., 1977).

Sequences obtained from positive samples were first submitted to a screening test using Phred-Phrap software version 23 (Ewing and Green, 1998; Ewing et al., 1998) in order to evaluate the electropherogram quality and to obtain consensus sequences from the alignment of sense and antisense sequences. The BLAST program (Altschul et al., 1990) was used to analyze the sequences of nucleotides (BLASTn), aiming to browse and compare with sequences previously deposited in an international database (GenBank) (Benson et al., 2002). All sequences that showed appropriate quality standards and identity with hemoplasmas were deposited in Genbank, except RNaseP sequences, whose small fragment size $(165 \mathrm{pb})$ precluded being deposited in the international database. Samples showing positive results for both $16 \mathrm{~S}$ rRNA and RNaseP protocols had their sequences concatenated, using the fragment merger software, version 1 (Bell and Kramvis, 2013). The sequences were aligned using Clustal/W (Thompson et al., 1994) in Bioedit v. 7.0.5.3 (Hall, 1999) and MAFFT software, version 7 (Katoh and Standley, 2013).

Phylogenetic inferences were based on Bayesian and Maximum Likelihood (ML) methods. The Bayesian inference analysis was performed with MrBayes 3.1.2 (Ronquist and Huelsenbeck, 2003). Markov chain Monte Carlo (MCMC) simulations were run for $10^{9}$ generations with a sampling frequency of every 100 generations and a burn-in of $25 \%$. The Maximum-likelihood (ML) analysis was inferred with RAxMLHPC BlackBox 7.6.3 (Stamatakis et al., 2008) (which includes an estimation of bootstrap node support), using 1000 bootstrapping replicates. The best model of evolution was selected by the program jModelTest2 (version 2.1.6) on XSEDE (Darriba et al., 2012), under the Akaike Information Criterion (AIC) (Posada and Buckley, 2004). All phylogenetic analyses were performed using CIPRES Science Gateway (Miller et al., 2010). The trees were examined in Treegraph 2.0.56-381 beta (Stover and Muller, 2010). Phylogenetic inferences based on ML and Bayesian methods were performed using the evolutionary model GTR + G + I. Mesorhizobium loti (KM192337), Brucella melitensis (AY513568) and Ochrobactrum anthropi (EU119263) were used as outgroups in 16S rRNA analysis. Clostridium innocuum (GQ456215; U64878) was used as outgroup in concatenated analysis (16S rRNA + RnaseP).

Logistic regression models were employed to assess the effect of the putative predictor variables (i.e. gender and animal species) on the logit of the probability of positivity for hemoplasmas. All analyses were performed using R software 3.0.2 (R Core Team, 2013).

Additionaly, an analysis of nucleotide polymorphisms of $16 \mathrm{~S}$ rRNA sequences obtained in the present study was performed. The sequences were aligned using Clustal/W (Thompson et al., 1994) in Bioedit v. 7.0.5.3 (Hall, 1999). The number of haplotypes, haplotype diversity (Hd) and nucleotide diversity ( $\mathrm{Pi}$ ) were estimated to explore the levels of genetic differentiation among the species of hosts with higher number of positive samples for hemoplasmas, using the program DnaSP 5, version 5.10.01 (Librado and Rozas, 2009).

\section{Results}

Twenty-four (77.4\%) N. nasua, three (3.8\%) C. thous, two (4.7\%) domestic dogs, one $(14.2 \%)$ L. pardalis and one $(0.9 \%)$ wild rodent $(O$. mamorae) were positive for both hemoplasmas-PCR protocols based on16S rRNA gene. Fourteen (4.6\%) N. nasua were also positive in PCR for hemoplasmas based on RnaseP gene. None of sampled marsupials orarthropods (tick or flea) showed positivity for Mycoplasma spp. All 16S rRNA sequences obtained from positive animals were deposited in the international database Genbank under the following accession numbers: KY002649-KY002679. Logistic regression results evidenced no significant difference $(\mathrm{P}>0.05)$ between sexes for positivity in PCR assays for Mycoplasma spp. However, compared to other animal species (ocelots, crab-eating foxes, domestic dogs and wild rodents), coatis showed a significantly ( $\mathrm{p}$-value $<0.01$ ) higher chance to have Mycoplasma spp. DNA detected in whole blood samples. Odds ratios for Mycoplasma spp. positivity between coatis and each of other animal species were all above 20.57 .

The BLAST analysis was performed with sequences obtained from 
Table 2

Maximum identity of 16S rRNA and RnaseP Mycoplasma spp. sequences detected in wild and domestic mammals sampled in southern Pantanal, Brazil, by BLAST analysis.

\begin{tabular}{|c|c|c|c|}
\hline Animal species & $\begin{array}{l}\text { Number of } \\
\text { sequences } \\
\text { analized }\end{array}$ & $\begin{array}{l}\text { Target } \\
\text { Gene }\end{array}$ & $\begin{array}{l}\text { Percentage of identity by } \\
\text { BLAST }^{\circ} \text { - analysis }\end{array}$ \\
\hline O. mamorae & 1 & 16S rRNA & $\begin{array}{l}\text { Uncultured Mycoplasma sp. } \\
\text { from a wild rodent, Brazil } \\
\text { (KT215634) } 100 \%\end{array}$ \\
\hline L. pardalis & 1 & & $\begin{array}{l}\text { 'Candidatus Mycoplasma } \\
\text { haemominutum' } \\
\text { (EU839985) } 99 \%\end{array}$ \\
\hline C. familaris & 2 & & $\begin{array}{l}\text { Mycoplasma haemocanis } \\
\text { (KP715859) } 100 \%\end{array}$ \\
\hline C. thous & 3 & & $\begin{array}{l}\text { Mycoplasma haemocanis } \\
\text { (KP715859) } 100 \%\end{array}$ \\
\hline N. nasua & 24 & & $\begin{array}{l}\text { Mycoplasma sp. (Raccon USA) } \\
\text { (KF743735) } 99 \%\end{array}$ \\
\hline N. nasua & 12 & RNaseP & $\begin{array}{l}\text { Mycoplasma } \\
\text { haemofelis } \\
\text { (JN368074) 91\% }\end{array}$ \\
\hline
\end{tabular}

an overlapping of approximately $600 \mathrm{bp}$ of two hemoplasmas-16S rRNA fragments (800 bp and $1000 \mathrm{bp}$ ), and from $165 \mathrm{bp}$ fragment of hemoplasmas-RnaseP gene. Twenty-four hemoplasmas-16S rRNA sequences obtained from $N$. nasua blood samples showed $99 \%$ identity with a sequence of Mycoplasma sp. detected in a raccon (Procyon lotor) sampled in the United States (KF743735). Three hemoplasmas-16S rRNA sequences obtained from $C$. thous blood samples and two hemoplasmas-16S rRNA sequences obtained from dogs' blood samples showed 100\% identity with M. haemocanis (KP715859). Hemoplasmas16S rRNA sequences obtained from one $L$. pardalis blood sample and one O. mamorae spleen sample showed $100 \%$ identity with 'Candidatus Mycoplasma haemominutum' (EU839985) and with Mycoplasma sp. sequence obtained from a Brazilian wild rodent (KT215634), respectively, based on BLAST analysis. Additionally, all 14 hemoplasmasRNAseP sequences obtained from $N$. nasua blood samples presented 91\% of identity with $M$. haemofelis (JN368074) (Table 2).

All hemoplasmas-16SrRNA sequences obtained from dogs' blood samples (KY002678, KY002679), two hemoplasmas-16S rRNA sequences obtained from C. thous (KY002677, KY002675) and ten hemoplasmas-16S rRNA sequences obtained from $N$. nasua (KY002652, KY002653, KY002657, KY002661, KY002662, KY002665, KY002667, KY002672, KY002673, KY002674) were grouped in the same large branch comprising 16S rRNA sequences of M. haemocanis (HQ918287, AY150973) and M. haemofelis (EU930823, KJ135316) previously deposited in Genbank, with clade support of 98 and 100, based on ML and Bayesian analyses, respectively (Figs. 2 and 3). A hemoplasma-16S rRNA sequence obtained from one $C$. thous blood sample (KY002676) and 14 hemoplasmas-16S rRNA sequences obtained from $N$. nasua blood samples (KY002651, KY002654, KY002655, KY002656, KY002658, KY002659, KY002660, KY002663, KY002664, KY002666, KY002668, KY002669, KY002670, KY002671) were pooled in a separate clade from the others Mycoplasma species previously detected, with clade support of 87 and 100,based on ML and Bayesian analyses, respectively (Figs. 2 and 3), but closely related with a new hemoplasma genotype obtained from a Brazilian capybara (FJ667773) and in the same large branch of M. coccoides (AY171918), 'Candidatus Mycoplasma turicensis' (KJ095696) and a new genotype detected in a synanthropic rodent from Brazil (KM203857), with clade support of 53 and 69, based on ML and Bayesian analyses, respectively (Figs. 2 and 3). The hemoplasma-16S rRNA sequence obtained from an $O$. mamorae wild rodent (KY002650) was positioned in the same clade of one hemoplasma-16S rRNA sequence obtained from $T$. fosteri wild rodent sampled in the same region of Pantanal, Brazil (KT215621), with clade support of 100 and 100, based on ML and Bayesian analyses, respectively (Figs. 2 and 3). All hemoplasmas-16S rRNA sequences obtained from $N$. nasua, C. thous, O. mamorae and dogs were grouped into the same large branch of "haemofelis group", based on ML and Bayesian analyses (Figs. 2 and 3). The hemoplasma-16S rRNA sequence obtained from one L. pardalis (KY002649) blood sample was placed in the same clade of 'Candidatus Mycoplasma haemominutum' (KJ135327), with clade support of 93 and 100, based on ML and Bayesian analyses, respectively, and in the same large branch of "suis group" (Figs. 2 and $3)$.

Regarding the concatenated phylogenetic analysis of hemoplasmas based on RnaseP and 16S rRNA genes, six Mycoplasma spp. sequences obtained from $N$. nasua blood samples were pooled in a separate clade from the others Mycoplasma species previously detected, with clade support of 100 and 100, based on ML and Bayesian analyses, respectively (Figs. 4 and 5), but in the same large branch of $M$. coccoides (AY171918; EU078619) and 'Candidatus Mycoplasma turicensis' (KJ095696; EF212002), with clade support of 91 and 100, based on ML and Bayesian analyses, respectively (Figs. 4 and 5). The remaining eight hemoplasmas RnaseP + 16S rRNA concatenated sequences obtained from $N$. nasua blood samples were grouped in the same large branch of M. haemofelis (KJ135316; EU078617) and M. haemocanis (AY150973; EU078618) with clade support of 100 and 100, based on ML and Bayesian analyses, respectively (Figs. 4 and 5).

One sequence obtained from $C$. thous blood sample (KY002676) and 14 sequences obtained from $N$. nasua blood samples (KY002651, KY002654, KY002655, KY002656, KY002658, KY002659, KY002660, KY002663, KY002664, KY002666, KY002668, KY002669, KY002670, KY002671), were pooled in a separate clade from other Mycoplasma species previously detected, based on the 16S rRNA and RnaseP phylogenetic analysis (Figs. 2-5).

The 16S rRNA alignment (1247pb) of 24 sequences obtained from coatis blood samples showed the presence of four haplotypes, haplotype diversity (hd): 0.569; standard deviation (SD): $=0.074$, nucleotide diversity (Pi): 0.05270 (SD $=0.00563$ ) and average number of nucleotide differences (k):19.44565 (Table 3). Nucleotide polymorphisms were not found in $120 \mathrm{bp}$ RnaseP gene fragment alignment of 14 sequences obtained from coatis blood samples. Fourteen sequences shared the same haplotype (\#hap 1), while the sequences (10) closed related to $M$. haemocanis/M. haemofelis showed tree different haplotypes (\#hap2, \#hap3, \#hap4) (Fig. 6).

\section{Discussion}

The present study showed the presence of Mycoplasma spp. DNA in blood or spleen samples of wild carnivores, domestic dogs and wild rodents in the region of Pantanal, state of Mato Grosso do Sul, centralwestern Brazil. To the best authors' knowledge, this was the first molecular detection of Mycoplasma spp. among wild coatis and crabeating foxes from Brazil.

The molecular analyses of hemoplasmas-16S rRNA sequences revealed a low (2/42) occurrence of $M$. haemocanis among sampled dogs. The occurrence of $M$. haemocanis (4.7\%) found in the present study was similar to that reported in dogs sampled in an urban area (4.2\%) located in the same state of Mato Grosso do Sul (Soares et al., 2016). On the other hand, the found occurrence of M. haemocanis was higher than that found in dogs sampled in the states of Pernambuco (Ramos et al., 2010), northeastern Brazil (1/205), and São Paulo (Alves et al., 2014) (3/154), but lower than that found in dogs sampled in the state of Rio Grande do Sul (17/331) (Valle et al., 2014). Only two studies reported the molecular detection of 'Candidatus M. haematoparvum' in dogs from Brazil, in the states of São Paulo (Alves et al., 2014) and Rio Grande do Sul (Valle et al., 2014). The results of the present study reinforces that the mostly common species of Mycoplasma parasitizing dogs in Brazil is M. haemocanis.

A genotype closely related to $M$. haemocanis/M. haemofelis was detected in blood samples from two crab-eating foxes in the present study, based on the molecular analysis of 16SrRNA sequences. 


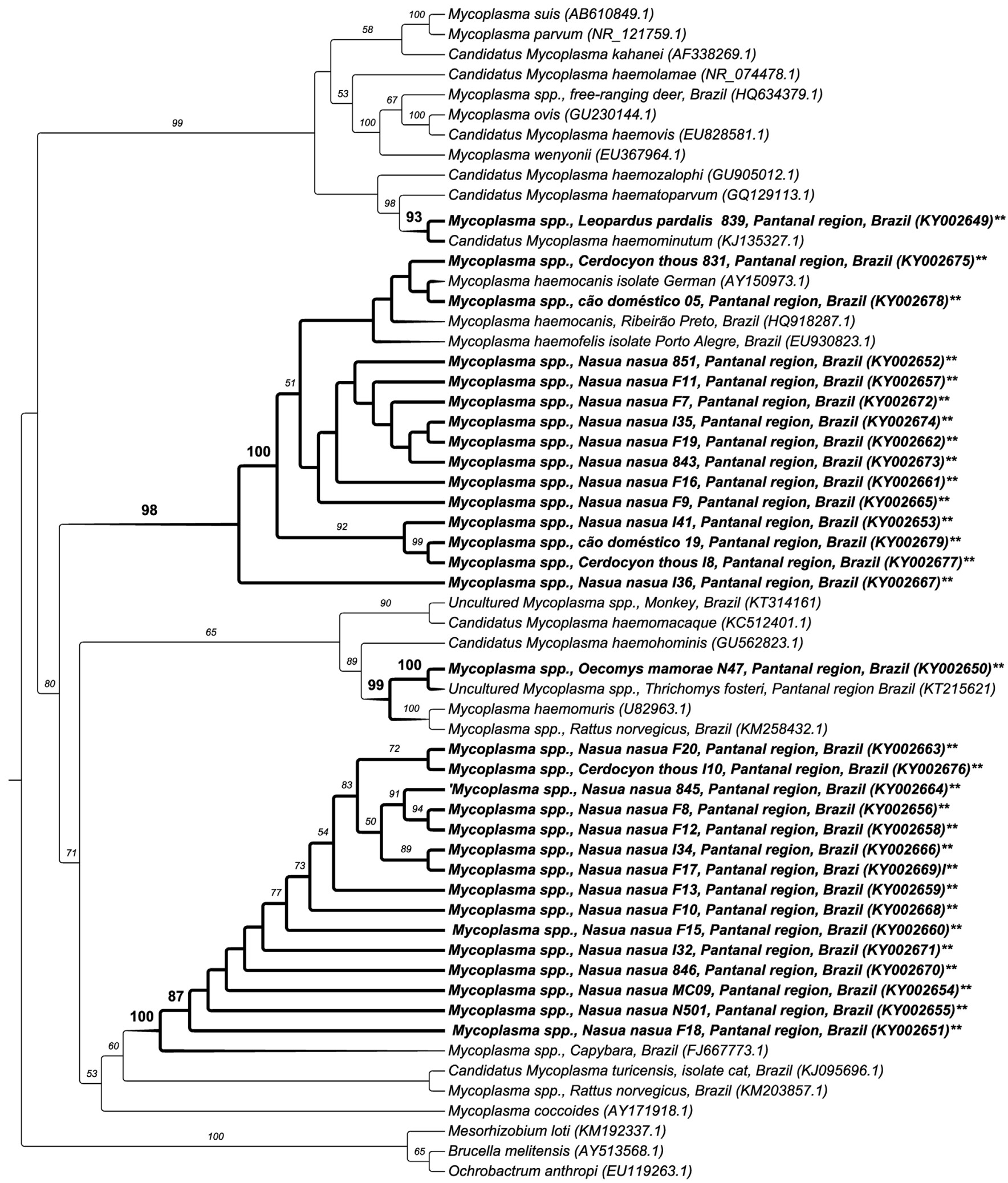

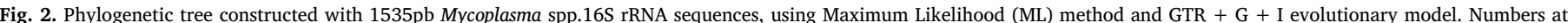
nodes correspond to ML bootstrap values over 50, using Mesorhizobium loti (KM192337), Brucella melitensis (AY513568) and Ochrobactrum anthropi (EU119263) as outgroups.

Unfortunately, the two positive C. thous samples did not show positivity to RnaseP PCR protocol, precluding the differentiation of these Mycoplasma species. In previous studies, a genotype closely related to M. haemocanis was detected in raccoon dogs (Nyctereutes procyonoides viverrinus) from Japan (Harasawa et al., 2014) and arctic foxes (Vulpes lagopus) from Canada (Mascarelli et al., 2015). Besides, genotypes closely related to M. haemocanis, M. haemofelis and 'Candidatus M. turicensis' were detected in Darwin's foxes (Lycalopex fulvipes) from Chile (Cabello et al., 2013). In Brazil, among wild canids maintained in captivity in zoos, two bush dogs (Speothos venaticus) and two European wolves (Canis lupus) were positive for Mycoplasma species closely related to 'Candidatus M. haematoparvum and "Candidatus M. haemo- 


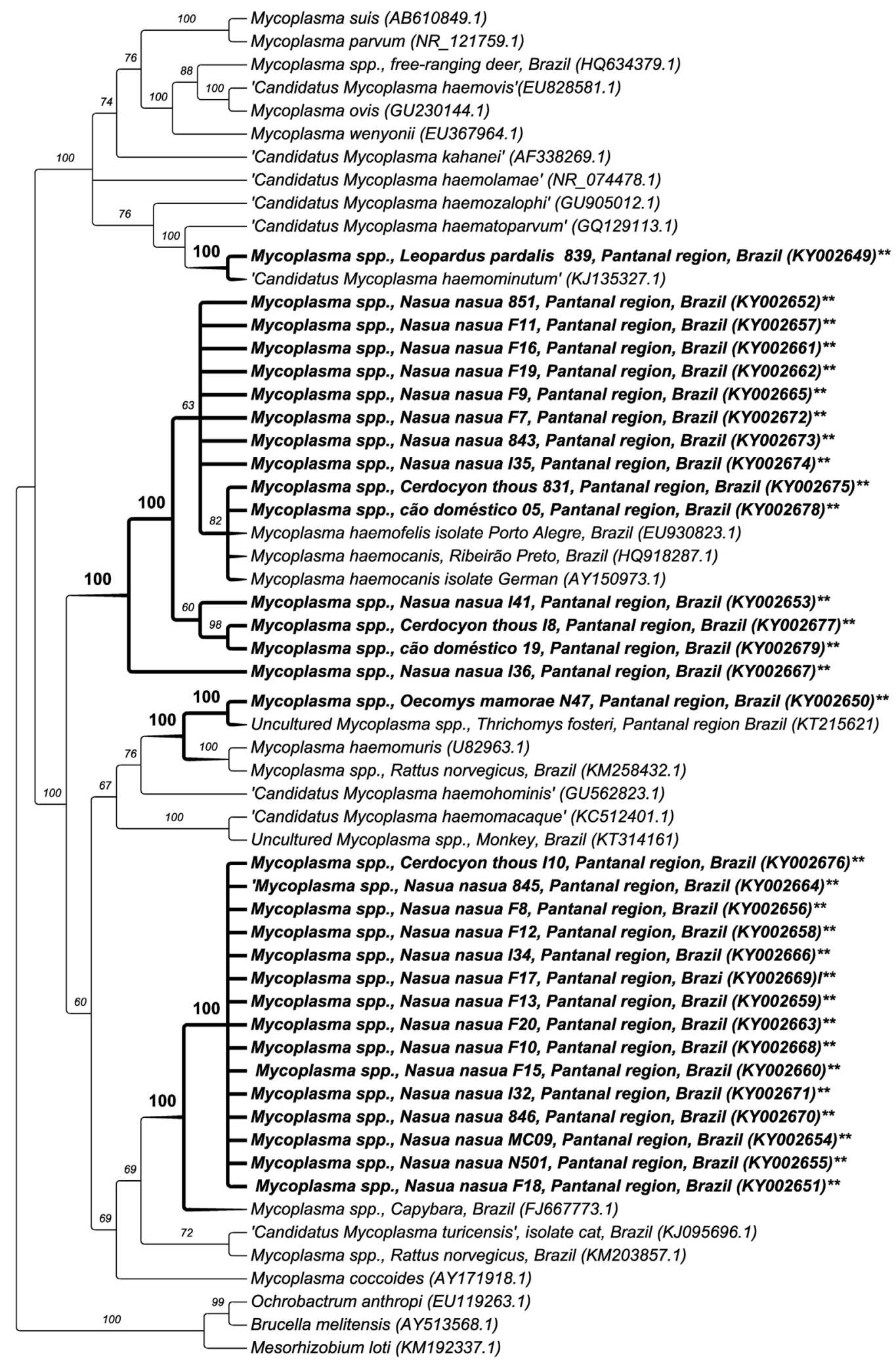

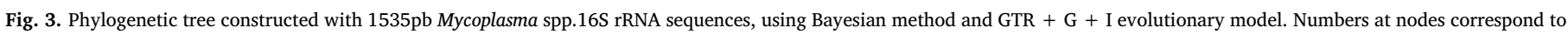
Bayesian posterior probabilities over 50, using Mesorhizobium loti (KM192337), Brucella melitensis (AY513568) and Ochrobactrum anthropi (EU119263) as outgroups.

minutum", respectively (André et al., 2011).

Mycoplasma haemofelis and 'Candidatus Mycoplasma haemominutum' were detected in the saliva and salivary glands of hemoplasma infected cats, suggesting that these bacteria could be transmitted by social interactions (Dean et al., 2008). Considering that, it could be hypothesized that the gregarious behavior of coatis (Blanco and Hirsch,
2006) may have contributed for a higher incidence of Mycoplasma spp. infection among this carnivore species compared to the other animal species sampled in the present study.

Among wild coatis, ten hemoplasmas sequences showed to be closely related to $M$. haemocanis/M. haemofelis based on 16S rRNA and RnaseP phylogenetic analyses. Additionally, a new 'Candidatus 


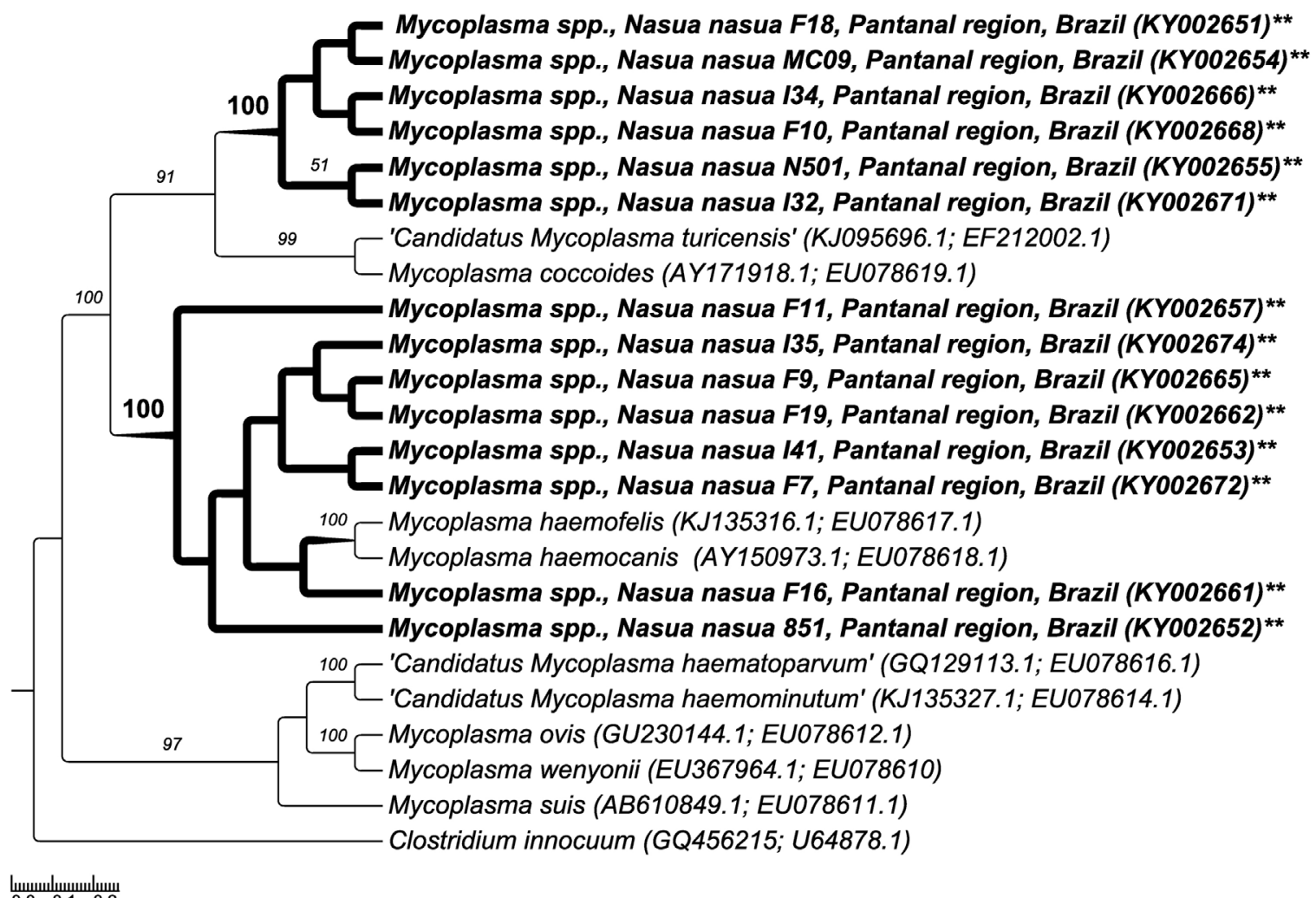

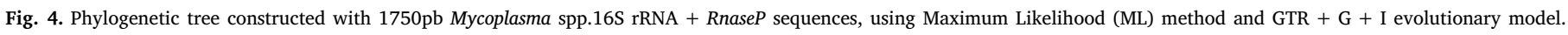
Numbers at nodes correspond to ML bootstrap values over 50, using Clostridium innocuum (GQ456215; U64878) as outgroup.

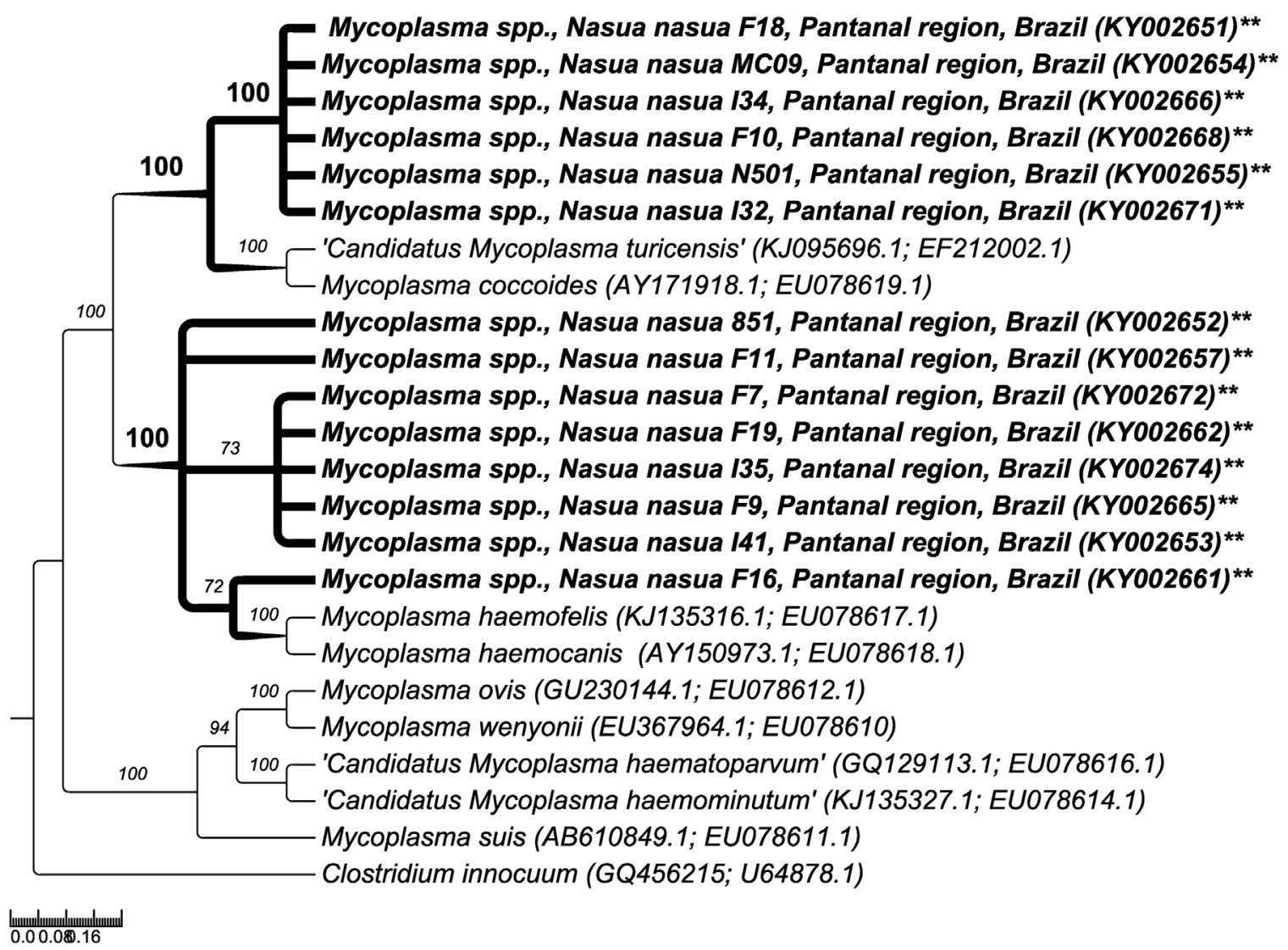

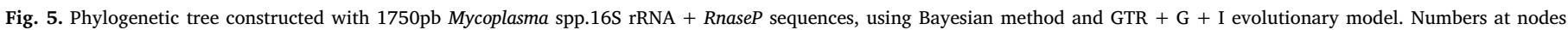
correspond to Bayesian posterior probabilities over 50, using Clostridium innocuum (GQ456215; U64878) as outgroup. 
Table 3

Polymorphisms of Mycoplasma spp. 16SrRNADNA sequences obtained from Nasua nasua blood samples.

\begin{tabular}{llllllll}
\hline $\begin{array}{l}\text { Population } \\
\text { (Hosts) }\end{array}$ & $\begin{array}{l}\mathrm{N}^{\circ} \text { of } \\
\text { 16SrRNA } \\
\text { sequences }\end{array}$ & AS & NVS & H & Hd & Pi & k \\
\hline N. nasua & 24 & 1247 & 48 & 4 & 0.569 & $\begin{array}{l}\mathrm{Pi}=0.05270 \\
(\mathrm{SD}=0.00563)\end{array}$ & 19.44565 \\
\end{tabular}

$\mathrm{N}^{\circ}$ of $16 \mathrm{~S}$ rRNA sequences, Number of $16 \mathrm{~S}$ rRNA hemoplasma sequences obtained from $N$. nasua blood samples; AS, Alignment Size; NVS, Number of Variable Sites; H, Number oh haplotypes; Hd, Haplotype diversity; Pi, Nucleotide Diversity; SD, Standard Deviation; k, Average number of nucleotide differences.

Mycoplasma' species is proposed for the hemoplasma detected in 14 coatis and one crab-eating fox, which grouped in a separate branch with high values of clade support, and was closely related to a new Mycoplasma genotype detected in a capybara from Brazil (Vieira et al., 2009), based on ML and Bayesian phylogenetic analyses of $16 \mathrm{~S}$ rRNA gene. The concatenated phylogenetic analysis of 16SrRNA and RnaseP Mycoplasma sequences also positioned six sequences obtained from coatis in a distinct branch with a significant value of clade support. Due to the inability to culture hemoplasmas in vitro, the only method to differentiate these species relies on the phylogenetic analysis. Although 16S rRNA and RnaseP are the most used target genes in phylogenetic analysis of hemoplasmas (Peters et al., 2008; Neimark et al., 2005), non-ribosomal genes (dnaK) have also been used (Harasawa et al., 2015). In addition to this, the 16S rRNA sequences obtained from coatis blood samples comprises only one haplotype (\#hap 1), which showed to be different from the others three haplotypes found in the 16SrRNA sequences obtained from coatis closely related to $M$. haemocanis/M haemofelis. Although the Mycoplas- ma sequences obtained from coatis and a crab-eating fox showed to be closely related to the new hemoplasma genotype detected in a Brazilian capybara, these genotypes were not positioned in the same clade, highlighting the circulation of a new genotype of Mycoplasma among carnivores in Pantanal region, Brazil.

'Candidatus Mycoplasma haemominutum' was the most common feline hemoplasma species found in previous studies involving Iberian lynxes (Lynx pardinus) from Spain, Eurasian lynxes (Lynx lynx) from Switzerland, lions (Panthera leo) from Tanzania, and seven Brazilian neotropic felid species namely Geoffroy's cats (Oncifelis geoffroyi), jaguarundis (Puma yaguaroundi), margays (Leopardus wiedii), ocelots (Leopardus pardalis), oncillas (Leopardus tigrinus), pumas (Puma concolor), and jaguars (Panthera onca) (Willi et al., 2007; André et al., 2011). On the other hand, 'Candidatus M. turicensis' was the most prevalent hemoplasma species among European wild cats (Felis silvestris silvestris) (Willi et al., 2007). The only report on hemoplasma infection in a Brazilian wild felid showed a coinfection with M. haemofelis and 'Candidatus M. turicensis' in an ocelot (Willi et al., 2007), whereas 'Candidatus M. haemominutum' was the only hemoplasma species detected in a wild ocelot in the present study, corroborating to previous reports on the occurrence of hemotrophic mycoplasmas in ocelots maintained in captivity in zoos in Brazil (André et al., 2011). Wild animals may be more susceptible to become infected by hemoplasmas when compared to those animals maintained in captivity, since they are more likely to be exposed to a great diversity of bloodsucking arthropods, multiple pathogens and aggressive interactions (Filoni et al., 2006). Further studies should be perform in order to sample a higher number of wild felids aiming to know the most common hemoplasma species circulating among wild Brazilian felids and the impact of infection on animal health.

The found occurrence of Mycoplasma among wild rodents sampled

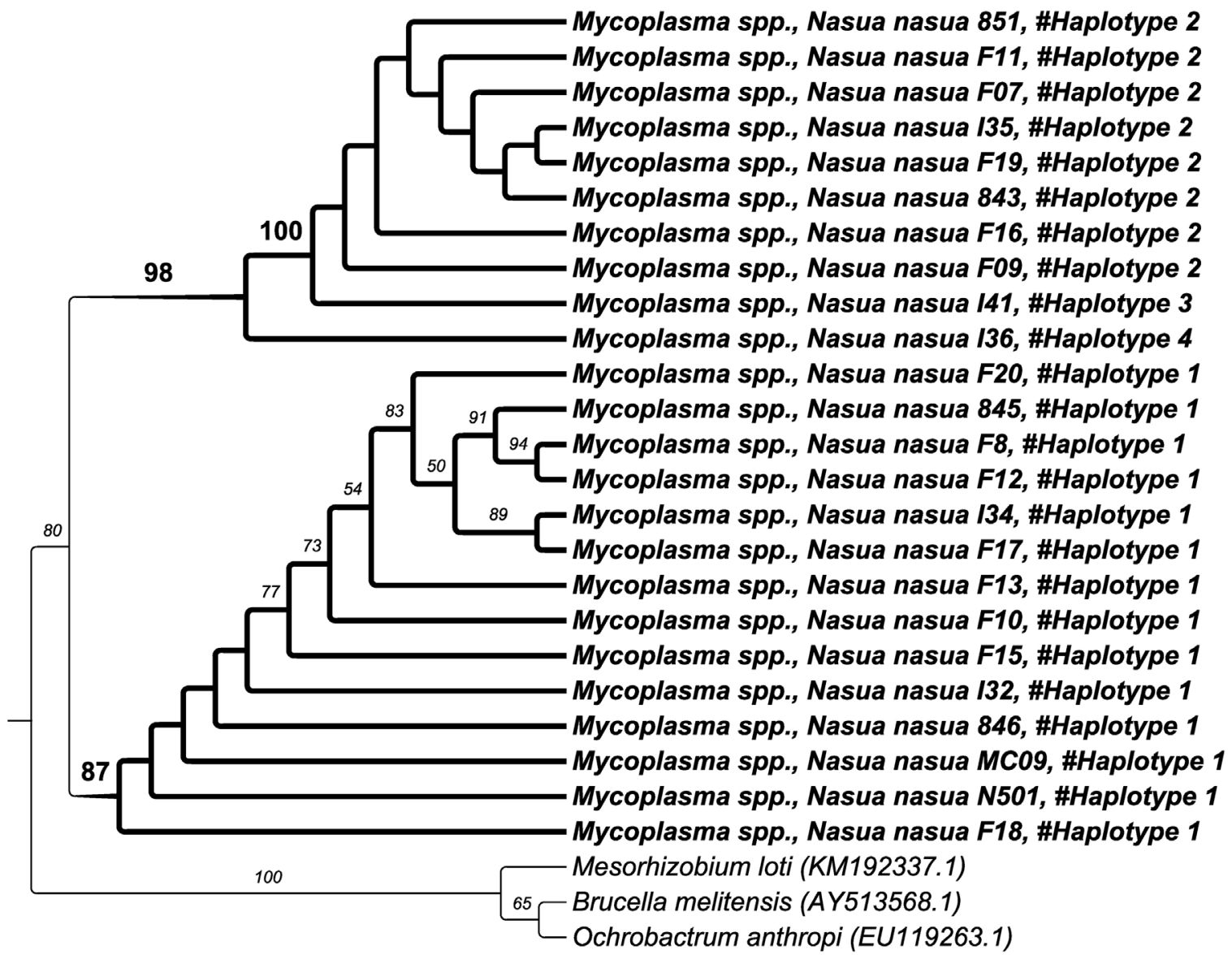

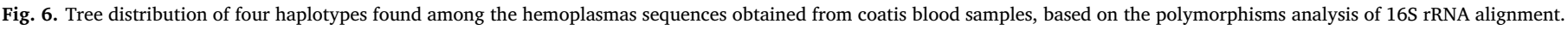


in the present study was lower $(1 / 110)$ than that found in a previous recent study involving wild rodents (4/32) in the Pantanal, Brazil (Gonçalves et al., 2015). However, the occurrence of Mycoplasma infection found among wild rodents in Pantanal biome in the above mentioned study was significantly lower than that found in the others three Brazilian biomes (Cerrado, Amazon Forest, and Atlantic Forest) (Gonçalves et al., 2015). Additionally, high occurrence of hemoplasmas was found among capybaras (64\%), synanthropic and laboratory rodents (Rattus novergicus) (63.5\%) from urban areas in the state of Paraná, Brazil (Vieira et al., 2009; Conrado et al., 2015). A closer contact among rodents from urban areas with different host species and arthropods could explain the differences observed in prevalence rates. In spite of that, a high diversity of Mycoplasma genotypes has been detected in rodents from Japan, Hungary and Brazil (Vieira et al., 2009; Sashida et al., 2013; Conrado et al., 2015; Gonçalves et al., 2015; Hornok et al., 2015). A genotype closely related to M. haemomuris was detected in a wild rodent (O. mamorae) in the present study. The same genotype has been already detected in wild rodents from the same biome Pantanal (Gonçalves et al., 2015), suggesting that M. haemomuris, besides being the most common hemoplasma species found in synantropic rodents (Conrado et al., 2015; Hornok et al., 2015) seems to be the main hemotrophic mycoplasma species parasitizing wild rodents in the Pantanal biome in Brazil.

Although bloodsucking arthropods are suspected to be the vectors of hemoplasmas, the real role of these ectoparasites in the transmission cycles remains inconclusive (Woods et al., 2005). Supporting that hypothesis, 'Candidatus M. haemominutum' and M. haemofelis were detected in fleas (Ctenocephalides felis) collect from cats in the USA (Lappin et al., 2006), although experimental attempts of hemoplasmas transmission between felines via fleas were inconclusive (Woods et al., 2005). In addition, $M$. haemofelis and "Candidatus M. haemominutum" DNA was detected in dog brown tick, $R$. sanguineus, collected from lions in Tanzania (Fyumagwa et al., 2008). The tick R. sanguineus s.l. is considered the main vector of $M$. haemocanis (Seneviratna et al., 1973). Despite of that, even in the localities where this tick species is well distributed and high rates of infestation are documented in Brazil (Labruna and Campos Pereira, 2001) the occurrence of hemotropic mycoplasmas in dogs was generally low (Ramos et al., 2010; Alves et al., 2014; Valle et al., 2014; Soares et al., 2016). In fact, there is only one study about the ability of $R$. sanguineus to transmit $M$. haemocanis to dogs (Seneviratna et al., 1973). The others reports were based only in positive statistical correlations between $M$. haemocanis infection and $R$. sanguineus infestation rates (Soares et al., 2016). Keeping that in mind, the role of the tick $R$. sanguineus in $M$. haemocanis epidemiology remains unclear. The lice Polypax spinulosa and Polyplax serrata are known to be able to transmit M. coccoides to rodents (Eliot, 1936; Berkenkamp and Wescott, 1988). Recently, Mycoplasma phylotypes were detected in fleas (Synosternus cleopatrae) collected from rodents (Gerbillus andersoni) from Israel, suggesting the possible participation of fleas as vectors of Mycoplasma spp. to rodents (Cohen et al., 2015). The possible arthropod vector of hemoplasmas among wild animals in Brazil remains unknown. In the present study, none of the ticks or fleas collected from wild animals showed to be positive for Mycoplasma spp. The participation of other arthropods or other transmission routes, such as aggressive interactions or predation among Brazilian wildlife should be better investigated.

In conclusion, the present study revealed that wild animals in southern Pantanal region, Brazil, are exposed to different species of hemotropic hemoplasmas; some of them are known to cause clinical diseases in domestic animals. Domestic dogs, some crab-eating foxes and $N$. nasua seemed to share the same Mycoplasma spp. species, closely related to $M$. haemocanis/M. haemofelis. The role of domestic dogs as a source of Mycoplasma infection to wild animals should be better investigated. On the other hand, wild felines and rodents appear to be infected by specific host species of Mycoplasma spp. The real role of arthropods in the hemoplasmas transmission cycles remains unknown.
Finally, probably a new genotype of Mycoplasma was detected among wild coatis and crab-eating foxes in the present study. Therefore, future studies are much needed in order to elucidate the main and alternatives routes of Mycoplasma spp. transmission and to estimate the impact of hemoplasma infection among the Brazilian wildlife from Pantanal biome.

\section{Acknowledgments}

We are thankful to Fundação de Amparo à Pesquisa do Estado de São Paulo (FAPESP) and Conselho Nacional de Desenvolvimento Científico e Tecnológico (CNPq) for the financial support to M.R. André (Process numbers \#2015/14896-1 and \#473575/2014-0, respectively) and for Doctorate Scholarship to K. C. M Sousa (Process \#2013/13186-5) and the Scientific Initiation Fellowship to C. T. Secato (Process \# 2016/01216-5) and to A. V. Oliveira (Bolsista Pró-Reitoria de Pesquisa da UNESP - Apoio aos Grupos Emergentes).

\section{References}

Altschul, S.F., Gish, W., Miller, W., Myers, E.W., Lipman, D.J., 1990. Basic local alignment search tool. J. Mol. Biol. 215, 403-410.

Alves, T.B., Faggion, S.A., Santos, E.V., Roberto, P.G., França, S.C., Fachin, A.L., Marins, M., 2014. Real-time PCR-based study of haemotrophic mycoplasmas in dogs from Ribeirão Preto, Brazil. Arch. Med. Vet. 46, 333-336.

André, M.R., Adania, C.H., Allegreti, S.M., Machado, R.Z., 2011. Hemoplasmas in wild canids and felids from Brazil. J. Zoo Wildl. Med. 42, 342-347.

André, M.R., Baccarim Denardi, N.C., Marques de Sousa, K.C., Gonçalves, L.R., Henrique, P.C., Grosse Rossi Ontivero, C.R., Lima Gonzalez, I.H., Cabral Nery, C.V., Fernandes Chagas, C.R., Monticelli, C., Alexandre de Santis, A.C., Machado, R.Z., 2014. Arthropod-borne pathogens circulating in free-roaming domestic cats in a zoo environment in Brazil. Ticks Tick Borne Dis. 5, 545-551.

Bell, T.G., Kramvis, A., 2013. Fragment merger: an online tool to merge overlapping long sequence fragments. Viruses 5, 824-833.

Benson, D.A., Mizrachi, I.K., Lipman, D.J., Ostell, J., Rapp, B.A., Wheeler, D.I., 2002. GenBank. Nucleic Acids Res. 30, 17-20.

Berkenkamp, S.D., Wescott, R.B., 1988. Arthropod transmission of Eperythrozoon coccoides in mice. Lab. Anim. Sci. 38, 398-401.

Birkenheuer, A.J., Levy, M.G., Breitschwerdt, E.B., 2003. Development andevaluation of a seminested PCR for detection and differentiation os Babesia gibsoni (Asian genotype) and B. canis DNA in canine blood samples. J. Clin. Microbiol. 41, 4172-4177.

Black, W.C., Piesman, J., 1994. Phylogeny of hard- and soft-tick taxa (Acari: ixodida) based on mitochondrial 16S rDNA sequences. Proc. Natl. Acad. Sci. 91 10034-10038.

Blanco, Y.D., Hirsch, B.T., 2006. Determinants of vigilance behavior in the ring-tailed coati (Nasua nasua): the importance of within-group spatial position. Behav. Ecol. Sociobiol. 61, 173-182.

Bonato, L., Figueiredo, M.A.P., Gonçalves, L.R., Machado, R.Z., André, M.R., 2015. Occurrence and molecular characterization of Bartonella spp. and hemoplasmas in neotropical primates from Brazilian Amazon. Comp. Immunol. Microbiol. Infect. Dis. $42,15-20$.

Braga, M.S.C.O., André, M.R., Freschi, C.R., Teixeira, M.C.A., Machado, R.Z., 2012 Molecular detection oh hemoplasma infection among cats from São Luís Island, Maranhão, Brazil. Braz. J. Microbiol. 43, 569-575.

Cabello, J., Altet, L., Napolitano, C., Sastre, N., Hidalgo, E., Dávila, J.A., Millán, J., 2013 Survey of infectious agents in the endangered Darwin's fox (Lycalopex fulvipes): high prevalence and diversity of hemotrophic mycoplasmas. Vet. Microbiol. 167, $448-454$.

Cohen, C., Toh, E., Munro, D., Dong, Q., Hawlena, H., 2015. Similarities and seasonal variations in bacterial communities from the blood of rodents and from theirflea vectors. ISME J. 9, 1662-1676.

Conrado, F.O., Do Nascimento, N.C., Dos Santos, A.P., Zimpel, C.K., Messick, J.B., Biondo, A.W., 2015. Occurrence and identification of hemotropic mycoplasmas (Hemoplasmas) in free ranging and laboratory rats (Rattus norvegicus) from two Brazilian zoos. BMC Vet. Res. 11, 286.

Darriba, D., Taboada, G.L., Doalho, R., Posada, D., 2012. jModelTest 2: more models,new heuristics and parallel computing. Nat. Methods 9, 772.

Dean, R.S., Helps, C.R., Jones, T.J.G., Tasker, S., 2008. Use of real-time PCR to detect Mycoplasma haemofelis and 'Candidatus Mycoplasma haemominutum' in the saliva and salivary glands of hemoplasma infected cats. J. Feline Med. Surg. 10, 413-417.

Eliot, C.P., 1936. The insect vector for the natural transmission Eperythrozoon coccoides in mice. Science 84, 397.

Ewing, B., Green, P., 1998. Base-calling of automated sequencer traces using phred. II Error probabilities. Genome Res. 8 (3), 186-194.

Ewing, B., Hillier, L., Wendl, M.C., Green, P., 1998. Base-calling of automated sequencer traces using phred. I. Accuracy assessment. Genome Res. 8 (3), 175-185.

Filoni, C., Catão-Dias, J.L., Bay, G., Durigon, E.L., Jorge, R.S., Lutz, H., HofmannLehmann, R., 2006. First evidence of feline herpesvirus, calicivirus, parvovirus, and Ehrlichia exposure in Brazilian free-ranging felids. J. Wildl. Dis. 42, 470-477.

Folmer, O., Black, M., Hoeh, W., Lutz, R., Vrijenhoek, R., 1994. DNA primers for 
amplification of mitochondrial cytochrome c oxidase subunit I from diverse metazoan invertebrates. Mol. Mar. Biol. Biotechnol. 3, 294-299.

Fyumagwa, R.D., Simmler, P., Willi, B., Meli, M.L., Sutter, A., Hoare, R., Dasen, G., Hofmann-Lehmann, R., Lutz, H., 2008. Mycoplasma species in Rhipicephalus sanguineus tick species collected on lions (Panthera lion) from Ngorongoro, Tanzania. S. Afr. J. Wildl. Res. 38, 117-122.

Gonçalves, L.R., Roque, A.L., Matos, C.A., Fernandes, S.J., Olmos, I.D., Machado, R.Z., André, M.R., 2015. Diversity and molecular characterization of novel hemoplasmas infecting wild rodents from different Brazilian biomes. Comp. Immunol. Microbiol. Infect. Dis. 43, 50-56.

Grazziotin, A.L., Duarte, J.M., Szabó, M.P., Santos, A.P., Guimarães, A.M., Mohamed, A., Vieira, R.F., de Barros Filho, I.R., Biondo, A.W., Messick, J.B., 2011. Prevalence and molecular characterization of Mycoplasma ovis in selected free-ranging Brazilian deer populations. J. Wildl. Dis. 47, 1005-1011.

Guimarães, A.M.S., Javarousky, M.L., Bonat, M., Lacerda, O., Balbinotti, B., Queiroz, L.G.P.B., Timenetsky, J., Biondo, A.W., Messick, J.B., 2007. Molecular detection of 'Candidatus Mycoplasma haemominutum' in a lion (Panthera lion) from a Brazilian zoological garden. Rev. Inst. Med. Trop. 49, 195-196.

Hall, T.A., 1999. BioEdit: a user-friendly biological sequence alignment editor and analysis program for Windows 95/98/NT. Nucl. Acids Symp. Ser. 41, 95-98.

Harasawa, R., Orusa, R., Giangaspero, M., 2014. Molecular evidence for hemotropic mycoplasma infection in a japanese badger (Meles meles anakuma) and a raccoon dog (Nyctereutes procyonoides viverrinus). J. Wildl. Dis. 50, 412-415.

Harasawa, R., Fujita, H., Kadosaka, T., Ando, S., Rikihisa, Y., 2015. Proposal for 'Candidatus Mycoplasma haemomuris subsp. musculi' in mice: and 'Candidatus Mycoplasma haemomuris subsp. ratti’ in rats. Int. J. Syst. Evol. Microbiol. 65, 734-737.

Hornok, S., Foldvári, G., Rigó, K., Meli, M.L., Gonczi, E., Répási, A., Farkas, R., Papp, I., Kontschán, J., Hofmann-Lehmann, R., 2015. Synantropic rodents and their ectoparasites as carriers of a novel haemoplasma and vector-borne, zoonotic pathogens indoors. Parasitol. Vectors 15, 27.

Katoh, K., Standley, D.M., 2013. MAFFT multiple sequence alignment software version 7: improvements in performance and usability. Mol. Biol. Evol. 30, 772-780.

Labruna, M.B., Campos Pereira, M., 2001. Carrapato em cães no Brasil. Clin. Vet. 30, $24-32$.

Lappin, M.R., Griffin, B., Brunt, J., Riley, A., Burney, D., Hawley, J., Brewer, M.M., Jensen, W.A., 2006. Prevalence of Bartonella species haemoplasma species, Ehrlichia species, Anaplasma phagocytophilum, and Neorickettsia risticii DNA in the blood of cats and their fleas in the United States. J. Feline Med. Surg. 8, 85-90.

Librado, P., Rozas, J., 2009. DnaSP v5: a software for comprehensive analysis of DNA polymorphism data. Bioinformatics 25, 1451-1452.

Maggi, R.G., Compton, S.M., Trull, C.L., Mascarelli, P.E., Mozayeni, B.R., Breitschwerdt, E.B., 2013a. Infection with hemotropic Mycoplasma species in patients with or without extensive arthropod or animals contact. J. Clin. Microbiol. 51, 3237-3241.

Maggi, R.G., Chitwood, M.C., Kennedy-Stoskopf, S., DePerno, C.S., 2013b. Novel hemotropic Mycoplasma species in white-tailed deer (Odocoileus virginianus). Comp. Immunol. Microbiol. Infect. Dis. 36, 607-611.

Mascarelli, P.E., Elmore, S.A., Jenkins, E.J., Alisauskas, R.T., Walsh, M., Breitschwerdt, E.B., Maggi, R.G., 2015. Vector-borne pathogens in arctic foxes, Vulpes lagopus, from Canada. Res. Vet. Sci. 99, 58-59.

Messick, J.B., 2003. New perspectives about Hemotrophic mycoplasma (formerly, Haemobartonella and Eperythrozoon species infections in dogs and cats. Vet. Clin. North. Am. Small Anim. Pract. 33, 1453-1465.

Miceli, N.G., Gavioli, F.A., Gonçalves, L.R., André, M.R., Sousa, K.C.M., Machado, R.Z. 2013. Molecular detection of feline arthropod-borne pathogens in cats in Cuiabá, state of Mato Grosso, central-western region of Brazil. Rev. Bras. Parasitol. Vet. 22, 385-390.

Miller, M.A., Pfeiffer, W., Schwartz, T., 2010. Creating the CIPRES Science Gateway for inference of large phylogenetic trees. Proceedings of the Gateway Computing Environments Workshop (GCE) 1-8.

Neimark, H., Wallace, P., Robinson, B.L., Stewart, L.B., 2005. Phylogenetic analysis and description of Eperythrozoon coccoides: proposal to transfer to the genus Mycoplasma as Mycoplasma coccoides comb. nov. and Request for an Opinion. Int. J. Syst. Evol. Microbiol. 55, 1385-1391.

Peters, I.R., Helps, C.R., McAuliffe, L., Neimark, H., Lappin, M.R., Gruffydd-Jones, T.J.,
Day, M.J., Hoelzle, L.E., Willi, B., Meli, M., Hofmann-Lehmann, R., Tasker, S., 2008. RNase P RNA gene ( $r p p B)$ phylogeny of hemoplasmas and other Mycoplasma species. J. Clin. Microbiol. 46, 1873-1877.

Posada, D., Buckley, T.R., 2004. Model selection and model averaging in phylogenetics: advantages of akaike information criterion and bayesian approaches over likelihood ratio tests. Syst. Biol. 53, 793-808.

Core Team, R., 2013. R: A Language and Environment for Statistical Computing. R Foundation for Statistical Computing, Vienna, Austria (Accessed 01.12.16). http:// www.R-project.org/.

Ramos, R., Ramos, C., Araújo, F., Oliveira, R., Souza, I., Pimentel Galindo, D.M.M., Santana, M., Rosas, E., Faustino, M., Alves, L., 2010. Molecular survey and genetic characterization of tick-borne pathogens in dogs in metropolitan Recife (northeastern Brazil). Parasitol. Res. 107, 1115-1120.

Ronquist, F., Huelsenbeck, J.P., 2003. MrBayes 3: Bayesian phylogenetic inference under mixed models. Bioinformatics 19 (12), 1572-1574.

Sanger, F., Nicklen, S., Coulson, A.R., 1977. DNA sequencing with chain-terminating inhibitors. Proc. Natl. Acad. Sci. U. S. A. 74 (12), 5463-5467.

Santis, A.C.A., Herrera, H.M., Sousa, K.C.M., Gonçalves, L.R., Denardi, N.C.B., Domingos, I.H., Campos, J.B., Machado, R.Z., André, M.R., 2014. Molecular detection of hemotrophic mycoplasmas among domiciled and free-roaming cats in Campo Grande, state of Mato Grosso do Sul, Brazil. Braz. J. Vet. Parasitol. 23, 231-236.

Sashida, H., Sasaoka, F., Suzuki, J., Watanabe, Y., Fujihara, M., Nagai, K., Kobayashi, S., Furuhama, K., Harasawa, R., 2013. Detection of hemotropic Mycoplasmas in freelinving brown sewer rats (Rattus norvegicus). J. Vet. Med. Sci. 75, 979-983.

Seneviratna, P., Weerasinghe, N., Ariyadasa, S., 1973. Transmission of Haemobartonella canis by the dog tick, Rhipicephalus sanguineus. Res. Vet. Sci. 14, 112-114.

Soares, R.L., Echeverria, J.T., Pazzuti, G., Cleveland, H.P., Babo-Terra, V.J., Friozi, E., Ramos, C.A., 2016. Occurrence of Mycoplasma haemocanis in dogs infested by ticks in Campo Grande, Mato Grosso do Sul, Brazil. Braz. J. Vet. Parasitol. 25, 360-363.

Sousa, K.C.M., Fernandes, M.P., Herrera, H.M., Benevenute, J.L., Santos, F.M., Rocha, F.L., Barreto, W.T.G., Macedo, G.C., Campos, J.B., Martins, T.F., Pinto, P.C.E.A. Barros-Battesti, D., Piranda, E.M., Cançado, P.H.D., Machado, R.Z., André, M.R., 2017. Molecular detection of Hepatozoon spp. in domestic dogs and wild mammals in southern Pantanal, Brazil with implications in the transmission route. Vet. Parasitol. 237, 37-46.

Stamatakis, A., Hoover, P., Rougemont, J., 2008. A rapid bootstrap algorithm for the RAxML Web servers. Syst. Biol. 57 (5), 758-771.

Stover, B.C., Muller, K.F., 2010. TreeGraph 2: Combining and visualizing evidence from different phylogenetic analyses. BMC Bioinf. 11 (7), 1-9.

Tasker, S., 2010. Hemotropic mycoplasmas: what's their real significance in cats? J. Feline Med. Surg. 12, 369-381.

Thompson, J.D., Higgins, D.G., Gibson, T.J., 1994. CLUSTAL W: improving the sensitivity of progressive multiple sequence alignment through sequence weighting, position specific gap penalties and weight matrix choice. Acids Res. 22, 1673-4680.

Valle, S.T., Messick, J.B., Santos, A.P., Kreutz, L.C., Duda, N.C.D., Machado, G., CorbellinI, L.G., Biondo, A.W., González, F.H., 2014. Identification: occurence and clinical findings of canine hemoplasmas in southern Brazil. Comp. Immunol. Microbiol. Infect. Dis. 37, 259-265.

Vieira, R.F., Molento, M.B., dos Santos, L.C., Moraes, W., Cubas, Z.S., Santos, A.P., Guimaraes, A.M., Mohamed, A., Barros Filho, I.R., Biondo, A.W., Messick, J.B., 2009. Detection of a novel hemoplasma based on 16S rRNA gene DNA in captiveand freeranging capybaras (Hydrochaeris hydrochaeris). Vet. Microbiol. 139, 410-413.

Willi, B., Filone, C., Catão-Dias, J.L., Cattori, V., Meli, M.L., Vargas, A., Martínez, F., Roelke, M.E., Ryser-Degiorgis, M.P., Leutenegger, C.M., Lutz, H., Hofmann-Lehmann, 2007. Wordwide occurrence of feline hemoplasma infections in wild felid species. J.Clin. Microbiol. 45, 1159-1166.

Woods, J.E., Brewer, M.M., Hawley, J.R., Wisnewski, N., Lappin, M.R., 2005. Evaluation of experimental transmission of Candidatus Mycoplasma haemominutum and Mycoplasma haemofelis by Ctenocephalides felis to cats. Am. J. Vet. Res. 66, 1008-1012.

dos Santos, A.P., dos Santos, R.P., Biondo, A.W., Dora, J.M., Goldani, L.Z., de Oliveira, S.T., de Sá Guimarães, A.M., Timenetsky, J., de Morais, H.A., González, F.H., Messick, J.B., 2008. Hemoplasma infection in HIV-positive patient. Braz. Emerg. Infect. Dis. 14, 1922-1924. 